\title{
KEANEKARAGAMAN HAYATI TANAMAN LUMUT (BRYOPHITHA) DI HUTAN SEKITAR WADUK KEDUNG BRUBUS KECAMATAN PILANG KECENG KABUPATEN MADIUN
}

\author{
Tiara Kusuma Wati ${ }^{1)}$, Bekti Kiswardianta ${ }^{2)}$, Ani Sulistyarsi ${ }^{3)}$ \\ 1,2,3) Program Studi Pendidikan Biologi IKIP PGRI Madiun \\ email : bektikiswardianta@gmail.com ${ }^{1)}$, anismasa81@yahoo.com ${ }^{2)}$
}

Diterima 20 Desember 2015, Disetujui 8 Maret 2016

\begin{abstract}
The aim of research to determine the diversity of plant species of moss in the forest areas around the reservoir Kedung Brubus Pilang Kenceng District of Madison County, based on the external structure and taxonomy, as the building blocks of high school biology lab manual mosses ( Bryophyta ) .Teknik research exploration, consisting of 6 points location as a decision mosses around the reservoir Kedung Brubus . Moss plants were found to be observed, identified, noted habitat, research location on the chart observations, documented and made herbarium. The results of the study there are 10 species Leucophanes glaucum, Thiudium investa, Polytrichum commune, Garovaglia plicata, Chenidium lychnites, Meteorium miquelianum, ricissa sp, Pogonotum cirrhatum, Fissidens cristatus, Barbrlla enervis.
\end{abstract}

Keywords: Bryophyta, biodiversity, reservoir, Kedung Brubus

\section{PENDAHULUAN}

Keanekaragaman hayati yang sangat tinggi merupakan suatu koleksi yang unik dan mempunyai potensi genetik yang besar pula. Hutan yang merupakan sumberdaya alam ini telah mengalami banyak perubahan dan sangat rentan terhadap kerusakan. Sebagai salah satu sumber devisa negara, hutan telah dieksploitasi secara besar-besaran untuk diambil kayunya. Ekploitasi hutan menyebabkan berkurangnya luasan hutan dengan sangat cepat. Keadaan semakin diperburuk dengan adanya konversi lahan hutan secara besar-besaran untuk lahan pemukiman, perindustrian, pertanian, perkebunan, peternakan serta kebakaran hutan yang selalu terjadi di sepanjang tahun.

Menurut Hendry Baiquni (2007) keanekaragaman alami atau keanekaragaman hayati, atau biodiversitas, adalah semua kehidupan di bumi meliputi tumbuhan, hewan, jamur dan mikroorganisme serta berbagai materi genetik yang dikandungnya dan keanekaragaman sistem ekologi di mana mereka hidup. Termasuk didalamnya kelimpahan dan keanekaragaman genetik relatif dari organisme-organisme yang berasal dari semua habitat baik yang ada di darat, laut maupun sistem-sistem perairan lainnya. serta jasad renik di dunia. Diperkirakan 30\% tanaman dan $90 \%$ hewan di Indonesia belum didata dengan lengkap dan didokumentasikan secara ilmiah. Salah satunya adalah tumbuhan lumut (Bryophyta).

Tumbuhan lumut merupakan salah satu kelompok tumbuhan dari keanekaragaman hayati yang belum banyak diteliti karena sepintas nampak 
tidak menarik perhatian dan bahkan sering dianggap sebagai penyebab lingkungan terlihat kotor. Namun, bila diperhatikan secara seksama beberapa jenis tumbuhan lumut ini cukup menarik, baik dari warna maupun kehidupannya yang berkelompok membentuk bantalan seperti karpet. Tumbuhan lumut sering dijumpai di tempat tempat yang lembab dan basah, misalnya di hutan dan hidup menempel pada berbagai substrat, antara lain misalanya tanah dalam rimba, batu-batu, cadas-cadas, gambut, kulit pohon, dan lain lain (Gembong, 2005)

Menurut Afiatry (2012) lumut tidak mempunyai akar, batang dan daun sejati. Lumut merupakan salah satu bagian kecil dari flora yang belum banyak tergali dan bagian penyokong keanekaragaman flora. Masih kurangnya informasi tentang lumut adalah suatu hal yang sangat disayangkan, Mengingat Indonesia memiliki kurang lebih 1500 jenis lumut yang hidup tersebut. Keanekaragaman tumbuhan Bryophyta di kawasan hutan sekitar waduk kedung brubus belum banyak terungkap.

Hutan merupakan vegetasi utama dan salah satu sumber daya alam yang sangat penting. Fungsi hutan salah satunya adalah sebagai hutan wisata. Hutan wisata adalah kawasan hutan yang diperuntukkan secara khusus untuk dibina dan dipelihara guna kepentingan wisata, pengembangan ilmu pengetahuan, dan pendidikan. (Karden,2003). Lingkungan hutan sekitar waduk kedung brubus menyediakan kondisi lingkungan dengan intensitas cahaya dan suhu udara yang relatif rendah serta kelembaban udara yang tinggi. Pada suhu rata-rata $10-30^{\circ} \mathrm{C}$ terdapat banyak jenis lumut yang tumbuh di tempat tersebut. Hasil observasi menurut perhutani KPH (Kesatun Pemangku Hutan) Saradan. luas wilayah hutan di sekitar waduk Kedung Brubus Kecamatan Pilang Kenceng Kabupaten Madiun adalah sekitar 456 ha. Hutan sekitar waduk kedung brubus memiliki kelembapan udara $\pm 2{ }^{\circ} \mathrm{C}$ yang menunjang pertumbuhan pada tanaman bryophita (Ellyzarti,2009).

Menurut Kimbal (2003), lumut merupakan tumbuhan kecil yang tingginya hanya sekitar 1-2 cm, dan bahkan yang paling besarpun umumnya tingginya kurang dari $20 \mathrm{~cm}$. Tumbuhan lumut merupakan tumbuhan yang sederhana biasanya tumbuh ditempat - tempat basah. Berdasarkan hal tersebut maka peneliti ingin melakukan penelitian lebih lanjut untuk mengungkap keanekaragaman tumbuhan lumut (Bryophyta) di hutan sekitar waduk Kedung Brubus Kecamatan Pilang Kenceng Kabupaten Madiun.

\section{METODE PENELITIAN}

Penelitian dilakukan di wilayah hutan sekitar waduk Kedung Brubus, Kecamatan Pilang kenceng Kabupaten Madiun. Waktu penelitian adalah waktu yang di sediakan dalam penelitian tersebut. Waktu yang diperlukan selama 6 bulan yaitu bulan Februari sampai Juli 2013. Peralatan yang digunakan dalam penelitian adalah: plastik, pinset, lup, kertas label, alat tulis, kamera, sasak, buku Taksonomi tumbuhan (Gembong, 2009), buku keanekaragaman tumbuhan tak berpembuluh (Muzzayanah, 2005), kunci determinasi tumbuhan lumut.

Teknik penelitian yang digunakan adalah teknik penelitian ekplorasi yaitu mengadakan pengamatan langsung terhadap tumbuhan lumut dengan menjelajahi wilayah hutan sekitar waduk Kedung Brubus, Kecamatan Pilang kenceng Kabupaten Madiun. Tumbuhan lumut yang ditemukan diamati, diidentifikasi, dicatat jenis dan populasinya pada tabel pengamatan lapangan serta didokumentasikan. Identifikasi tumbuhan lumut dilakukan pada tingkat genus dan kemudian pada tingkat spesies. Metode yang digunakan untuk pengambilan tumbuhan lumut dengan cara menentukan 
titik lokasi yang akan digunakan sebagai tempat penelitian. Lokasi tersebut terdiri dari 6 titik lokasi sebagai pengambilan tumbuhan lumut yaitu: 1) lokasi sekitar gerbang masuk wilayah hutan. 2) lokasi sepanjang pinggiran jalan menuju kantor dinas KPH. 3) lokasi sepanjang pinggiran jalan menuju jembatan pertama. 4) lokasi sepanjang pinggiran jalan menuju jembatan kedua. 5) lokasi sepanjang pinggiran jalan menuju gerbang masuk waduk Kedung Brubus. 6) lokasi sekitar area waduk Kedung Brubus. Pengambilan contoh tumbuhan lumut yang ditemukan dengan memotret tumbuhan lumut yang ditemukan di setiap titik pengamatan, mencatat data lapangannya dan mengambil jenis-jenis tumbuhan lumut yang ditemukan disetiap titik pengamatan, tumbuhan lumut yang telah diambil dihitung dan dimasukkan kedalam kantong plastik yang selanjutnya diidentifikasi dan dibuat herbarium.

\section{HASIL DAN PEMBAHASAN}

\section{Hasil Ekplorasi di Lapangan}

Berdasarkan hasil ekplorasi di setiap titik pengamatan titik lokasi tersebut sebangai berikut: 1) Lokasi sekitar gerbang masuk wilayah hutan, 2) lokasi sepanjang pinggiran jalan menuju kantor dinas $\mathrm{KPH}$, 3) lokasi sepanjang pinggiran jalan menuju jembatan pertama, 4) lokasi sepanjang pinggiran jalan menuju jembatan kedua, 5) lokasi sepanjang pinggiran jalan menuju gerbang masuk waduk Kedung Brubus, 6) lokasi sekitar area waduk Kedung Brubus. Berdasarkan 6 titik lokasi totoal keseluruhan individu lumut yang telah dikumpulkan di lapangan setelah teridentifikasi terdapat 10 spesies tumbuhan lumut yang berbeda dengan berbagai habitat ada yang tumbuh di tanah, epifit pada, batu, batang pohon teh dan batang pohon jati yang telah lapuk.

\section{Hasil Identifikasi Tumbuhan Lumut}

Berdasarkan hasil ekplorasi dan observasi yang telah dilakukan di wilayah hutan sekitar waduk Kedung Brubus, Kecamatan Pilang kenceng Kabupaten Madiun. dengan enam titik lokasi yang berbeda, jumlah total individu spesies tumbuhan lumut yang berhasil ditemukan pada seluruh stasiun pengamatan adalah 10 spesies lumut yang terdiri dari 2 kelas, 9 ordo, 9 famili dan 10 genus, adapun spesies yang ditemukan antara lain : Leucophanes glaucum, Thiudium investa, Polytrichum commune, Garovaglia plicata, Chenidium lychnites, Meteorium miquelianum, ricissa sp, Pogonotum cirrhatum, Fissidens cristatus, Barbrlla enervis.

Keadaan hutan sekitar waduk Kedung Brubus Kecamatan Pilang Kenceng Kabupaten Madiun yang teduh dan kelembabannya yang relatif tinggi suhu sekitar $20^{\circ} \mathrm{C}$, banyak ditemukan lumut karena pada kondisi yang demikian sangat mendukung untuk perkecambahan spora lumut, pertumbuhan maupun perkembangannya. Hasil penelitian yang telah diperoleh untuk mengetahui keanekaragaman jenis tiap titik lokasi pengamatan. Total keseluruhan individu lumut yang telah dikumpulkan di lapangan setelah teridentifikasi terdapat 10 spesies yang berbeda dengan berbagai habitat. Penyebaran dan kelimpahan vegetasi tumbuhan lumut antara satu tempat dengan tempat lainnya berbeda-beda karena dipengaruhi oleh faktor biotik dan abiotik.

Faktor biotik merupakan faktor organisme hidup disekitar lumut yang secara langsung mempengaruhi keadaan maupun perkembangannya. Adapun faktor biotik yang hidup disekitar lumut antara lain: bentuk kehidupan tumbuhan lumut, daya adaptasi yang berbeda terhadap kondisi habitatnya, serta beberapa tumbuhan jati yang cukup rimbun dapat menghalangi masuknya cahaya matahari kepermukaan tanah. Faktor abiotik yang 
mempengaruhi tumbuhan lumut antara lain: suhu, kelembaban, intensitas cahaya matahari yang terhalang oleh daun pepohonan jati. Hal tersebut disebabkan lumut mampu hidup tanpa memerlukan syarat hidup yang cukup tinggi, sehingga lumut dapat berkembang baik di daerah manapun, apalagi di daerah hutan.

Hasil tersebut ditemukan 10 spesies tumbuhan lumut yang terletak pada lokasi berbeda yaitu: titik lokasi 1 (sekitar gerbang masuk wilayah hutan), ditemukan dua spesies tumbuhan lumut yaitu Riccia $s p$ dan Fissidens cristatus. Lokasi pertama yaitu pada sekitar gerbang masuk wilayah hutan, terdapat kondisi lingkungan intensitas cahaya yang cukup terang karena lokasi ini tidak begitu rindang di bandingkan lokasi lainya, maka lumut yang ditemukan tidak begitu banyak spesiesnya. Titik lokasi 2 (sepanjang pinggiran jalan menuju kantor dinas KPH), ditemukan lima spesies tumbuhan lumut yaitu Riccia sp, Garovaglia Plicata, Chenidium lychnites, Meteorium miquelianum, dan Barbrlla enervis. Titik lokasi yang kedua terdapat pada sepanjang pinggiran jalan menuju kantor dinas $\mathrm{KPH}$, kondisi lingkungannya yang lebih rindang dibandingkan titik lokasi yang pertama, sehingga kelembaban tinggi dan intensitas cahaya rendah. Maka lumut tumbuh dengan sangat subur pada lokasi ini. Titik lokasi 3 (pinggiran jalan menuju jembatan pertama), ditemukan lima spesies tumbuhan lumut yaitu Polytrichum commune, Riccia sp, Garovaglia plicata, Meteorium miquelianum, dan Pogonotum cirrhatum. Titik lokasi yang ketiga terdapat pada sepanjang pinggiran dari kantor KPH sampai jalan menuju jembatan pertama, kondisi lingkungan pada lokasi ini lebih rindang karena terdapat pohon jati yang berumur ribuan tahun yang mempunyai daun yang lebat, sehingga beragam tumbuhan lumut yang ditemukan di lokasi ini. Titik lokasi 4 (sepanjang pinggiran jalan menuju jembatan kedua), ditemukan empat spesies tumbuhan lumut yaitu Leucophanes glaucum, Thiudium investa, Polytrichum commune, dan Chenidium lychnites. Titik lokasi yang keempat terdapat pada sepanjang pinggiran jalan menuju jembatan kedua, lokasi ini juga berada di tengah-tengah hutan, sehingga kondisinya juga sangat rindang, intensitas cahaya sangat rendah, kelembaban sangat tinggi dan suhu juga semakin dingin.

Lingkungan yang menjamin seperti ini maka tumbuhan lumut tumbuh sangat subur dan terdapat spesies tumbuhan lumut yang berbeda. Titik lokasi 5 (sepanjang pinggiran jalan menuju gerbang masuk waduk Kedung Brubus), ditemukan tiga spesies tumbuhan lumut yaitu Thiudium investa, Fissidens cristatus dan Barbrlla enervis. Titik lokasi yang ke lima terdapat pada sepanjang pinggiran jalan menuju gerbang masuk waduk Kedung Brubus, kondisi lingkungan pada lokasi ini tidak serindang lokasi 4, karena lokasi ini menuju keluar arah hutan sehingga suhu juga semakin panas dan kelembapan semakin rendah, maka hanya terdapat dua spesies tumbuhan lumut saja yang di temukan. Titik lokasi 6 (sekitar area waduk Kedung Brubus), ditemukan tiga spesies tumbuhan lumut yaitu Leucophanes glaucum, Polytrichum commune, dan Meteorium miquelianum. Titik lokasi 6 terdapat pada sekitar area waduk Kedung Brubus, pada lokasi ini kondisi lingkungan yang terdapat intensitas cahaya yang cukup tinggi sehingga suhu juga semakin tinggi jadi hanya ditemukan tiga spesies tumbuhan lumut.

Hutan sekitar waduk Kedung Brubus tempat areal penelitian merupakan daerah yang memiliki banyak pohon jati sehingga memiliki banyak serasah dari daun-daun yang gugur dan mengakibatkan rendahnya $\mathrm{pH}$ dan intensitas cahaya di Hutan sekitar waduk Kedung Brubus ini relatif rendah, 
hal ini disebabkan masih lebatnya kanopi pohon jati, sehingga menghalangi matahari yang sampai ke dasar hutan karena intensitas cahaya ini akan berpengaruh terhadap suhu dan kelembaban, yaitu semakin rendah intensitas cahaya yang sampai ke permukaan bumi, maka suhu akan semakin rendah dan kelembaban semakin tinggi. Hasil ini sesuai pendapat Ellyzarti (2009) yang menyatakan bahwa tumbuhan lumut biasa hidup pada tempat yang lembab sehingga suhunya biasa pada derajat yang rendah, pada suhu rata-rata 10-30 derajat celcius terdapat banyak jenis lumut yang tumbuh di tempat tersebut. Selain itu kelembaban juga mendukung pertumbuhan lumut, pada umumnya lumut memerlukan kelembaban yang relatif tinggi untuk menunjang pertumbuhannya. Lumut dapat hidup pada kisaran kelembaban antara 70\%-98 \%, faktor $\mathrm{pH}$ tanah juga berpengaruh terhadap pertumbuhan lumut. $\mathrm{pH}$ yang berkisar antara 4,9-8,3, sangat baik untuk pertumbuhan lumut.

Hasil ekplorasi di lapangan habitat tumbuhan lumut di lokasi penelitian tercatat bahwa habitat lumut ada yang tumbuh pada substrat berupa tanah, epifit pada batang pohon jati, epifit pada batang pohon jati yang telah lapuk dan pada batu. Hasil ini sesuai pendapat Florentina (2009) yang menjelaskan bahwa habitat lumut di tanah karena pada tanah menyebabkan beberapa substrat untuk perkecambahan spora maupun pertumbuhan lumut menjadi stabil. Pada saat musim penghujan spora lumut jatuh ketanah sehingga tumbuh menjadi tumbuhan lumut baru, ada juga yang hanyut terbawa air sehingga jarang yang ditemukan lumut tumbuh bersubstrat tanah. Pada batang pohon karena kondisi lingkungan yang lembab dilokasi penelitian cukup mendukung untuk perkecambahan spora, pertumbahan dan perkembangan lumut terutama dibatang pohon dan pada batang pohon yang telah lapuk merupakan media yang baik bagi lumut karena kayu yang telah mengalami pelapukkan mampu menyerap dan menyimpan air cukup banyak di antara selsel kayunya.

\section{KESIMPULAN DAN SARAN}

\section{Simpulan}

Keanekaragaman jenis tumbuhan lumut tiap titik lokasi pengamatan berbeda ditemukan sepuluh spesies tumbuhan lumut yaitu: Leucophanes glaucum, Thiudium investa, Polytrichum commune, Garovaglia plicata, Chenidium lychnites, Meteorium miquelianum, ricissa sp, Pogonotum cirrhatum, Fissidens cristatus, Barbrlla enervis.

\section{Saran}

Identifikasi keragaman tumbuhan lumut dapat diperluas sampai daerah lain sehingga diperoleh referensi keragaman yang semakin banyak. Dapat juga dilakukan pengukuran indeks keragaman yang dapat memperjelasn keragaman spesies yan ada.

\section{DAFTAR PUSTAKA}

Afiatry Putrika.2012. Komunitas Lumut Epifit Di Kampus Universitas Depok. FPMIPA Universitas Indonesia Depok. (tesis). (Online) http://lontar.ui.ac.id/file?file=digital/ 20314104-T30873-

Komunitas\%20lumut.pdf. Diakses 4 Maret 2013.

Ellyzarti. 2009. Kekayaan Jenis Tumbuhan Lumut di Gunung Pesawaran di Hutan Raya Wan Abdur rahman,Propinsi Lampung. Seminar Hasil Penelitian \& Pengabdian Kepada Masyarakat, Unila.(Online).http://lemlit.unila.ac.i d/file/arsip\%202010./Prosiding\%20 
Dies\%20Natalis/KELOMPOK\%20

A/04\%20Ellyzarti\%20-

\%20FMIPA.pdf. Diakses tgl 7 Maret 2013.

Florentina Indah Windadri. 2009. Keragaman Lumut di Resort Karang Ranjang, Taman Nasional Ujung Kulon, Banten. Jurnal Teknologi Lingkungan, Vol 10, No 1, Jakarta, januari 2009, ISSN 1441-1318X, hlm. 19-25. http://isjd.pdii.lipi.go.id/admin/jurna 1/101091925.pdf. Diakses tgl 7-032013.

Gembong Tjitrosoepomo. 2005. Taksonomi Tumbuhan Obat obatan.Yogyakarta: Gajah Mada University Press.

Gembong Tjitrosoepomo. 2009. Taksonomi Tumbuhan Tumbuhan Scizophyta, Thallophyta, Bryophyta, pteridophyta. Yogyakarta: Gajah Mada University Press.

Hendry Baiquni. 2007. Pengelolaan Keanekaragaman Hayati. (Online). http://www.dcita.gov.au/cca//upload s/2013/03.pdf. Diakses tgl 7-03$\underline{2013}$.

Kimbal.2003.Biologi Edisi Lima-Jilid 2. Jakarta:Erlangga

Karden Eddy Sontang Manik. 2003 Pengelolaan Lingkungan Hidup.Jakarta: Anem Kasong Anem.

Muzayyinah. 2005. Keanekaragaman Tumbuhan Tak Berpembuluh. Surakarta:Universitas Negeri Surakarta. 